\title{
Ontogeny of Excitatory Spinal Neurons Processing Distinct Somatic Sensory Modalities
}

\author{
Yi Xu, ${ }^{1 \star}$ Claudia Lopes, ${ }^{1 \star}$ Hagen Wende, ${ }^{2}$ Zhen Guo, ${ }^{3}$ Leping Cheng, ${ }^{3}$ Carmen Birchmeier, ${ }^{2}$ and Qiufu $\mathrm{Ma}^{1}$ \\ ${ }^{1}$ Dana-Farber Cancer Institute and Department of Neurobiology, Harvard Medical School, Boston, Massachusetts 02115, ${ }^{2}$ Department of Neuroscience, \\ Max Delbrück Center, 13125 Berlin, Germany, and ${ }^{3}$ Institute of Neuroscience, Shanghai Institutes for Biological Sciences, Chinese Academy of Sciences, \\ Shanghai 200031, China
}

Spatial and temporal cues govern the genesis of a diverse array of neurons located in the dorsal spinal cord, including dI1-dI6, $\mathrm{dIL}_{\mathrm{A}}$, and $\mathrm{dIL}_{\mathrm{B}}$ subtypes, but their physiological functions are poorly understood. Here we generated a new line of conditional knock-out $(C K O)$ mice, in which the homeobox gene $T l x 3$ was removed in $\mathrm{dI}_{5}$ and $\mathrm{dIL}_{\mathrm{B}}$ cells. In these $C K O$ mice, development of a subset of excitatory neurons located in laminae I and II was impaired, including itch-related GRPR-expressing neurons, PKC $\gamma$-expressing neurons, and neurons expressing three neuropeptide genes: somatostatin, preprotachykinin 1, and the gastrin-releasing peptide. These CKO mice displayed marked deficits in generating nocifensive motor behaviors evoked by a range of pain-related or itch-related stimuli. The mutants also failed to exhibit escape response evoked by dynamic mechanical stimuli but retained the ability to sense innocuous cooling and/or warm. Thus, our studies provide new insight into the ontogeny of spinal neurons processing distinct sensory modalities.

\section{Introduction}

The dorsal horn of the spinal cord processes diverse somatic sensory information, including pain, itch, touch, cold, and warm (Craig, 2003; Todd, 2010). Early electrophysiological and morphological studies suggest the existence of modality selective spinal neurons (Christensen and Perl, 1970; Han et al., 1998), which is further supported by recent cell ablation and behavioral studies (Sun et al., 2009; Mishra et al., 2012; Mishra and Hoon, 2013). For example, neurons expressing the gastrinreleasing peptide receptor (GRPR) or the natriuretic polypeptide $b$ receptor (Npra) are required to sense itch, but not pain (Sun et al., 2009; Mishra and Hoon, 2013). However, how modality-selective spinal neurons emerge during development is still poorly understood.

Early during development, eight groups of molecularly distinct dorsal horn neurons have been identified, namely, dI1-dI6, $\mathrm{dIL}_{\mathrm{A}}$, and $\mathrm{dIL}_{\mathrm{B}}$ (Gross et al., 2002; Müller et al., 2002; Helms and Johnson, 2003) (see Fig. 1A). Based on differential expression of the homeodomain protein Lbx1, they are divided into (1) Lbx1negative class A excitatory neurons (dI1-3), which are derived

\footnotetext{
Received Nov. 29, 2012; revised Aug. 3, 2013; accepted Aug. 7, 2013

Author contributions: Y.X., C.L., Z.G., L.C., and Q.M. designed research; Y.X., C.L., Z.G., L.C., and Q.M. performed research; H.W. and C.B. contributed unpublished reagents/analytic tools; Y.X., C.L., Z.G., L.C., and Q.M. analyzed data; Y.X., C.L., L.C., C.B., and Q.M. wrote the paper.

The work done in the Q.M. laboratory was supported by the National Institutes of Health, National Institute of Neurological Disorders and Stroke Grant R01NS047710. We thank Dr. Silvia Arber for the Tau-loxp-STOP-lox-mGFPIRES-NLS-LacZ reporter mice; Dr. Jean-Francois Brunet for the Phox2a antibody; and Drs. Clifford Woolf, Wendy Knowlton, Fu-Chia Yang, and Bo Duan for critical discussions and comments.

The authors declare no competing financial interests.

*Y.X. and C.L. contributed equally to this work.

Correspondence should be addressed to Dr. Qiufu Ma, Dana-Farber Cancer Institute and Department of Neurobiology, Harvard Medical School, 1 Jimmy Fund Way, Boston, MA 02115. E-mail: Qiufu_Ma@dfci.harvard.edu.

DOI:10.1523/JNEUROSCI.5512-12.2013

Copyright $\odot 2013$ the authors $\quad 0270-6474 / 13 / 3314738-11 \$ 15.00 / 0$
}

from progenitors expressing the transcription factor Olig3, and (2) Lbx1-expressing class B neurons, derived from Olig3negative progenitors (see Fig. 1A) (Gross et al., 2002; Müller et al., 2002, 2005). Class B neurons are further divided into glutamatergic excitatory neurons ( $\mathrm{dI} 5$ and $\mathrm{dIL}_{\mathrm{B}}$ ) marked by the expression of the homeobox proteins Lmx1b and Tlx3, and GABAergic/ glycinergic inhibitory neurons ( $\mathrm{dI} 4, \mathrm{dI} 6$, and $\mathrm{dIL}_{\mathrm{A}}$ ) marked by the expression of the homeobox proteins Pax2 and Lhx2/9 (Gross et al., 2002; Müller et al., 2002; Qian et al., 2002; Helms and Johnson, 2003; Cheng et al., 2004, 2005; Glasgow et al., 2005; Rebelo et al., 2010).

Previously, we and others reported that the Tlx 3 homeobox gene is necessary for proper development of $\mathrm{dI} 3$, $\mathrm{dI} 5$, and $\mathrm{dIL}_{\mathrm{B}}$ excitatory neurons in the dorsal spinal cord, including specification of the glutamatergic and peptidergic transmitter phenotypes (Qian et al., 2002; Cheng et al., 2004; Xu et al., 2008; Guo et al., 2012). A recent study shows that class A dI 3 neurons are involved with sensory motor coordination, such as hand grasp (Bui et al., 2013). The focus of this study, however, is the physiological functions of class $\mathrm{B}$ dI5 and $\mathrm{dIL}_{\mathrm{B}}$ neurons, which are still unknown.

Genetic fate mapping shows that the majority of Tlx3 lineage neurons are enriched in superficial laminae (I-III), although also scattered throughout the ventral laminae (Xu et al., 2008). Because dI 3 neurons are enriched in the deep dorsal horn (Helms and Johnson, 2003; Bui et al., 2013), it can be certain that those Tlx3 lineage neurons located in the superficial laminae must be derived from dI5 and $\mathrm{dIL}_{\mathrm{B}}$ neurons. Superficial laminae normally receive inputs from primary sensory afferents that transmit pain-, itch-, and temperature-related sensory information (Todd, 2010). To determine to what degree $\mathrm{dI} 5$ and $\mathrm{dIL}_{\mathrm{B}}$ neurons process these types of somatic sensory information, here we used Lbx1-Cre mice (Sieber et al., 2007) to selectively remove Tlx3 in these neurons. Subsequent histochemical and behavioral analy- 
ses provide new insight into the ontogeny of spinal neurons processing distinct types of somatic sensory modalities.

\section{Materials and Methods}

Animals. The generation of mice carrying the Tlx3 conditional null allele $\left(T l \times 3^{F /+}\right)$, the $L b x 1^{c r e}$ mouse line, the Tl $x 3^{C r e}$ mice, and the Tau-loxpSTOP-lox-mGFP-IRES-NLS-LacZ reporter line had been described previously (Hippenmeyer et al., 2005; Sieber et al., 2007; Xu et al., 2008; Lopes et al., 2012). In all timed matings, the morning that vaginal plugs were observed was considered to be E0.5. Genotypes were identified by PCR analysis of genomic DNA extracted from mouse tail tissue, and the following PCR primers were used to identify the floxed and deleted Tl $x 3$ alleles:5'-TGTTTCGCCTCCTTTGCTCG-3' and5'-GTTGGATGGAAG CAAAGATAG-3'. For histochemical studies, mice at P28 or younger ages were used. For behavioral analyses, mutant and control littermates at P21-P28 were used. All animal procedures are contained in protocols reviewed and approved by the Animal Care and Use Committees at the Dana-Faber Cancer Institute. Both males and females were used for the studies.

In situ hybridization and immunostaining. Detailed methods for singlecolor in situ hybridization and in situ hybridization combined with fluorescent immunostaining had been described previously (Liu et al., 2010). The following in situ probes were described previously, including SOM, Tac1, VGLUT2, and GRPR (Cheng et al., 2004; Xu et al., 2008). GRP in situ probe was amplified with gene-specific sets of PCR primers and cDNA template prepared from postnatal day 0 (P0) mouse spinal cords with a final fragment size of $0.387 \mathrm{~kb}$. The following antibodies were used for single or double immunostaining: rabbit anti-Pax2 (1:500, Zymed Laboratories), rabbit anti-VGLUT1 (1:1000, Swant), rabbit anti-phospho-ERK (1:250, Cell Signaling Technology), rabbit anti-Pkc $\gamma(1: 500$, Santa Cruz Biotechnology), and chick anti-lacZ (1:500, Abcam). The rabbit anti-Tlx3 (1:500) and guinea pig anti-Tlx3 (1:500) were acquired from C. Birchmeier at MaxDelbruck-Center for Molecular Medicine, Berlin, Germany, and rabbit anti-Phox2a was a gift from Dr. Jean-Francois Brunet at Centre National de la Recherche Scientifique, Paris, France. Sections were processed with immunofluorescence by incubating overnight with primary antibody and $1 \mathrm{~h}$ at room temperature with appropriate fluorescence-conjugated secondary antibodies (Invitrogen).

Counting p-ERK ${ }^{+}$cells. To count $\mathrm{p}-\mathrm{ERK}^{+}$spinal cells induced by heat, four pairs of P28 control and mutant mice were used, and the right hindpaw of each of these mice was dipped into a $50^{\circ} \mathrm{C}$ water bath for $20 \mathrm{~s}$ while holding the mouse by its neck, tail, and the left paw. Five minutes later, the mouse was killed and perfused transcardially with $4 \%$ paraformaldehyde in $0.1 \mathrm{M}$ phosphate buffer, $\mathrm{pH}$ 7.4. The lumbar spinal cord was removed from L3 to L6, and transverse sections (20 $\mu \mathrm{m}$ thickness) were cut and processed for p-ERK immunohistochemistry. Cells with a clear nuclear morphology and staining levels clearly above background were counted. The total number of $\mathrm{p}-\mathrm{ERK}^{+}$cells per set of sections through the L3-L6 spinal cord was determined, and values were presented as mean \pm SD. The differences between control and mutant samples were subjected to a Student's $t$ test, with $p<0.05$ considered significant.

Behavioral analysis. All pain and itch behavioral tests were performed as previously described (Liu et al., 2010). All animals $\left(T l \times 3^{F / / F} ; L b x 1^{\text {cre }}\right.$ mutants and $T l x 3^{F / F}$ or $T l x 3^{F /+}$ control littermates) were acclimatized to the behavioral testing apparatus for at least three "habituation" sessions. Two days before the injection, the nape of the neck was shaved after brief anesthesia with isoflurane ( $2 \%$ in $100 \%$ oxygen). A total of $10 \mu \mathrm{g}$ of Compound 48/80 (Sigma-Aldrich), $100 \mu \mathrm{g}$ of PAR2 agonist SLIGRL$\mathrm{NH} 2$ (Bachem), or $200 \mu \mathrm{g}$ of chloroquine (Sigma-Aldrich) in $50 \mu \mathrm{l}$ of sterile saline were injected intradermally into the nape, and a camcorder (Sony model DCR-SR220) was positioned to video-record the behavior of mice. The video recording was played back and scratching bouts were counted. The experimenter was blinded to the genotype of the animals, and only the bouts to the shaved region were counted. To measure heat sensitivity, we placed mice on a hot plate (IITC) and the latency to hindpaw flicking, licking, or jumping was measured. The hot plate was set to $50^{\circ} \mathrm{C}$ with a cutoff time of $60 \mathrm{~s}$, or to $54^{\circ} \mathrm{C}$ with a cutoff time of $30 \mathrm{~s}$. All animals were tested sequentially with a minimum of 5 min between tests.
Capsaicin was intradermally administrated in a dosage of $2.5 \mu \mathrm{g} / 10 \mu \mathrm{l}$ into the right hindpaw, and the duration of lifting, licking, and flinching was measured. To measure sensitivity to noxious cold, the cold plate (IITC) was set to $0^{\circ} \mathrm{C}$. The mice were video-recorded for $120 \mathrm{~s}$, and the combined number of hindpaw flicking, licking, or jumping was measured.

For the temperature chamber assay, animals were allowed to explore adjacent surfaces, with one held at $20^{\circ} \mathrm{C}$ and the other ranging from $30^{\circ} \mathrm{C}$ to $5^{\circ} \mathrm{C}$. The mice were video-recorded for $5 \mathrm{~min}$, and the percentages of time staying at $20^{\circ} \mathrm{C}$ chamber were determined. The acetone evaporation cooling assay was performed as previously described (Knowlton et al., 2011) with some modifications. Mice were acclimated for $10 \mathrm{~min}$ in an elevated wire grid. A syringe with a piece of rubber tubing attached to the end was filled with acetone and the plunger depressed so that a small drop of acetone formed at the top of the tubing. The syringe was raised to the hindpaw from below, depositing the acetone drop on the paw. The test was repeated for 10 times ( 5 times for each paw), with intervals of $3 \mathrm{~min}$. Responses were video-recorded, and duration times of lifting, licking, flinching, shacking, and rotating on the torso were determined. To measure punctate mechanical sensitivity, we placed animals on an elevated wire grid and the lateral plantar surface of the hindpaw stimulated with calibrated von Frey monofilaments $(0.0174-4.57 \mathrm{~g})$. The paw withdrawal threshold for the von Frey assay was determined using Dixons up-down method (Chaplan et al., 1994). To measure dynamic mechanical sensitivity, the middle part of the right hindpaw was stimulated by light stroking with a cotton swab, in the direction from heel to toe. The test was repeated three times, with intervals of 10 seconds. For each test, a score of 0 indicates no movement, and a score of 1 is a lifting of the stimulated paw and/or walking way. For each mouse, the accumulative scores of three tests were used to indicate "the dynamic score" shown in Figure $7 A$.

To measure sensorimotor coordination, we performed the rotarod test. Initially, mice were habituated for $1 \mathrm{~min}$ at a rotating speed of $4.0 \mathrm{rpm} / \mathrm{s}$. For the actual test, we set the ramp to start at a velocity of $4.0 \mathrm{rpm} / \mathrm{s}$, with a continuous acceleration of $0.4 \mathrm{rpm} / \mathrm{s}$. The time points when mutant and control mice fell off the ramp were recorded. Data for the different behavioral assays are represented as the mean \pm SE. Statistical significance was assessed with the Student's $t$ test, with $p<0.05$ considered significant. The experimenter was blinded to the genotype of animals.

\section{Results}

Generation of $T l x 3^{F / F} ; L b x I^{C r e /+}$ conditional knock-out mice

Tlx3 null mice die at birth (Shirasawa et al., 2000). We recently generated a mouse line carrying a conditional null allele of $T l \times 3$ (Lopes et al., 2012), referred to as $T l x 3^{F /+}$. To study the physiological functions of class $\mathrm{B}$ dI5 and $\mathrm{dIL}_{\mathrm{B}}$ neurons, we crossed $T l \times 3^{F /+}$ mice with Lbx1-Cre mice (Sieber et al., 2007) to generate $\mathrm{Tl} \times 3^{\mathrm{F} / \mathrm{F}} ; \mathrm{Lb} \times \mathrm{I}^{\mathrm{Cre} /+}$ mice, referred to here as conditional knock-out $(C K O)$ mice. As indicated by developmental ontogeny of spinal neurons (Fig. 1A), in these CKO mice, Tlx 3 was removed selectively in Lbx1-expressing class B dI5 and $\mathrm{dIL}_{\mathrm{B}}$ neurons (Fig. $1 \mathrm{~A}$ ). In wild-type mice, expression of both Tlx3 and Lbx1 is initiated immediately in newly formed postmitotic neurons (Gross et al., 2002; Müller et al., 2002; Qian et al., 2002). We found that Tlx3 expression in the dorsal spinal cord was still detected at E12.5 in CKO mice (Fig. $1 B$ ) but was largely eliminated by E16.5 (data not shown). At P21, persistent Tlx3 expression, which was detected in superficial dorsal horn laminae in wild-type mice (Fig. $1 C$, arrow), was not detected in $C K O$ mice (Fig. $1 C$ ), suggesting that Tlx3-persistent neurons belong to Lbx1 lineage neurons. This is consistent with class $B$ dorsal horn excitatory neurons $\left(\mathrm{dI}_{5} / \mathrm{dIL}_{\mathrm{B}}\right)$ being defined by the expression of the homeobox protein Lmx1b (Gross et al., 2002; Müller et al., 2002), and persistent Tlx3 being confined to these $\mathrm{Lmxlb}^{+}$spinal neurons (Rebelo et al., 2010).

We found that CKO mice survived to postnatal stages (see below). In the hindbrain, Tlx3 is expressed transiently in, but 
necessary for proper development of, several Lbx1-negative class A neurons that are involved in respiration control, including noradrenergic (NA) neurons and the nucleus of the solitary tract (NTS) in the hindbrain (Qian et al., 2001, 2002; Sieber et al., 2007). Development of these Lbx1-negative neurons was naturally unaffected in CKO mice because Lbx1-Cre was used for making conditional knockouts, as indicated by the normal expression of (1) the homeobox gene Phox $2 b$, a marker for NTS neurons, and (2) the dopamine $\beta$ hydroxylase, a marker for NA neurons (data not shown) (Qian et al., 2001). In Tlx3 complete null mice, the loss of NA and NTS neurons causes a failure in central respiration control and neonatal lethality (Shirasawa et al., 2000; Qian et al., 2001). Accordingly, the preservation of these neurons in $C K O$ mice explains why these mutants survive.

\section{Selective impairment of lamina I/II neurons in $\mathrm{CKO}$ mice}

Tlx3 is expressed persistently in neurons located in the superficial dorsal horn, but transiently in more ventral laminae (Xu et al., 2008). With the preservation of early Tlx3 expression in CKO mice, we hypothesized that the development of Tlx3persistent neurons might be preferentially impaired. Before we tested this hypothesis, we first examined which laminae contain Tlx3-persistent neurons. VGLUT1 is the vesicular glutamate transporter expressed in peripheral low threshold myelinated mechanoreceptors and proprioceptors that terminate in the inner layer of lamina II and more ventral laminae (Li et al., 2003). Double immunostaining showed that the ventral portion of Tlx3-persistent neurons was intermingled with most dorsally localized VGLUT1 ${ }^{+}$terminals (Fig. $2 A$ ), and as described below, corresponded to $\mathrm{PKC} \gamma^{+}$ neurons that represent the inner layer of lamina II (Neumann et al., 2008). Thus, Tlx3-persistent neurons are confined to laminae I and II.

We then found that development of lamina I/II neurons was compromised in $C K O$ mice. The somatostatin neuropeptide gene $(S O M)$ is expressed in both excitatory and inhibitory neurons, with Tlx3-dependent $\mathrm{SOM}^{+}$excitatory neurons located in the superficial laminae (Xu et al., 2008). Double staining of SOM mRNA and VGLUT1 showed that SOM expression was eliminated in the P21 CKO superficial dorsal horn but still detected in more ventral laminae (Fig. 2B). Loss of SOM expression occurred by E16.5 (data not shown) and at both lumbar (Fig. 2B) and cervical (Fig. 2C) levels at P21. The preprotachykinin gene (Tac1) encodes two neuropeptides: substance P and neurokinin A (Hökfelt, 1991). There are two waves of Tacl expression in the dorsal spinal cord. We reported previously that the early wave is established at embryonic stages and enriched in the deep dorsal horn
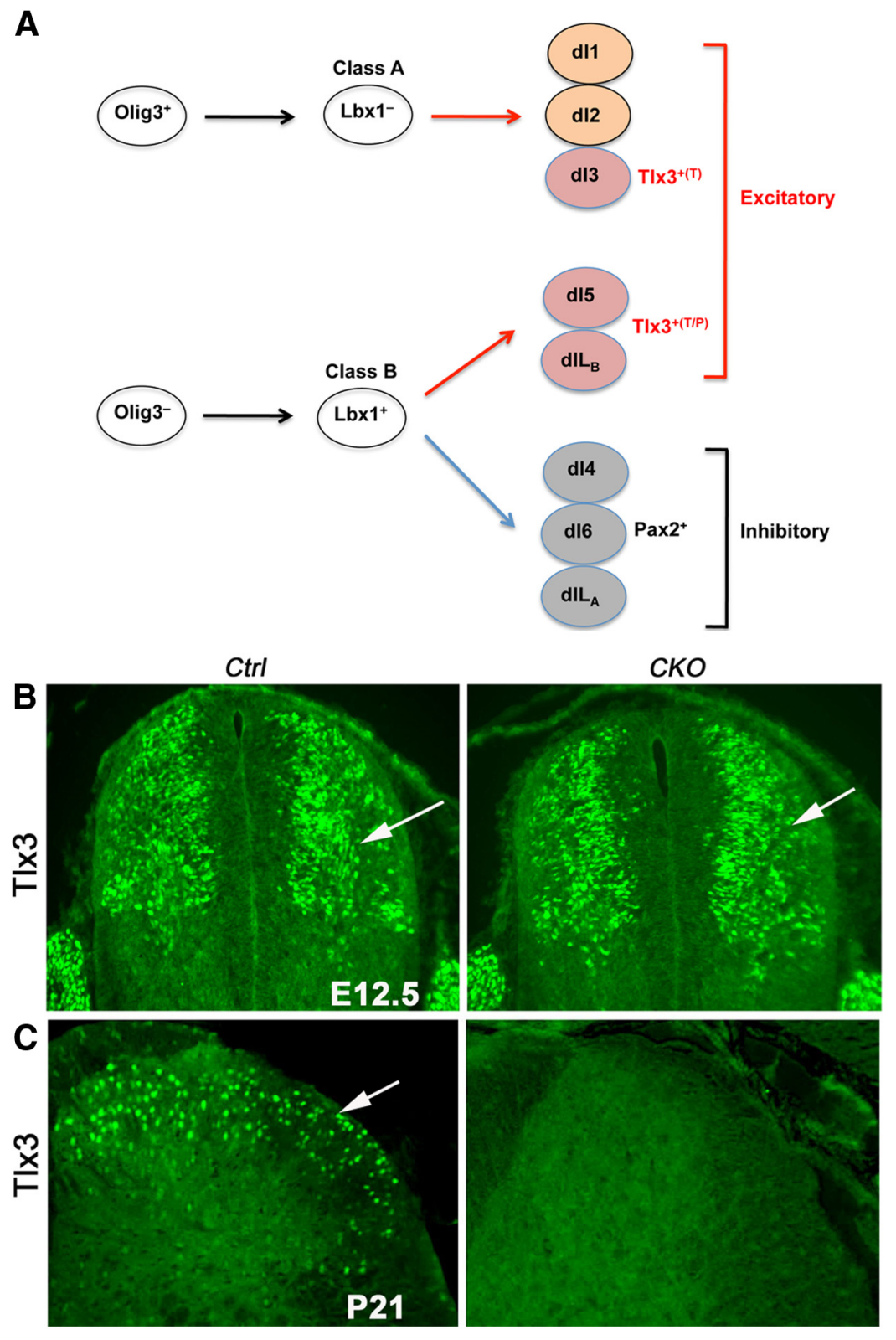

Figure 1. Ontogeny of spinal dorsal horn neurons and generation of $C K O$ mice. $A$, Schematics showing the ontogeny of eight t groups of dorsal horn neurons $\left(\mathrm{dl} 1-6, \mathrm{dlL}_{\mathrm{A}}, \mathrm{dL}_{\mathrm{B}}\right)$. Tlx $3^{+}(\mathrm{T})$, Neurons expressing Tlx3 transiently; Tlx ${ }^{+(\mathrm{T} / \mathrm{P})}$, neurons xpressing Tlx3 transiently or persistently. $B, C$, Tlx3 immunostaining on transverse spinal sections at indicated stages and genoTlx3 expression was observed in the superficial dorsal horn of $\operatorname{trl} /$ mice (C, arrow) but abolished in $(K O$ mice (C).

(Fig. 2D, arrowheads) (Xu et al., 2008). Here, we found a late wave of $\mathrm{Tacl}^{+}$neurons that emerged during postnatal development and were located in lamina II (Fig. 2D, arrow). In CKO mice, whereas the late wave of Tac1 expression in lamina II was eliminated (Fig. 2D, arrows), the early wave in deep laminae was at least partially preserved (Fig. $2 D$, arrowheads). Thus, the $\mathrm{SOM}^{+}$and $\mathrm{Tacl}^{+}$subsets of excitatory neurons that are located at laminae I and II are selectively compromised in CKO mice.

Because Tac1 expression is eliminated in Tlx3 complete null mice (Xu et al., 2008), the preservation of a subset of $\mathrm{Tac}^{+}$ neurons in $C K O$ mice suggests that the development of some Tlx3-transient deep dorsal horn is unaffected in CKO mice. To further support this, we examined additional markers. A subset of Tlx3-transient dI5 neurons is marked by the expression of 


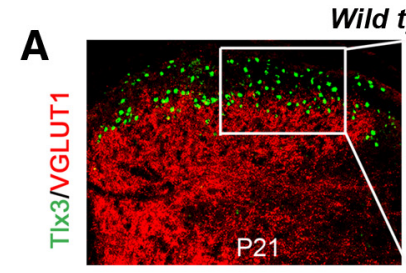

Wild type

B

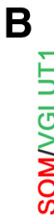
Ctrl
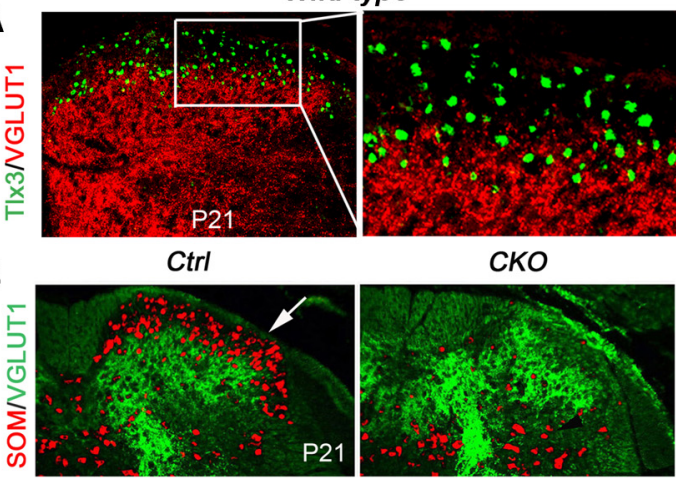

C

D

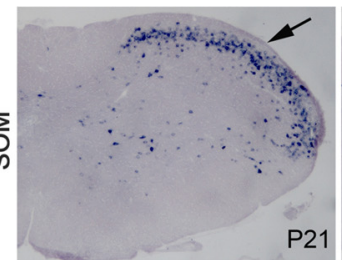

D
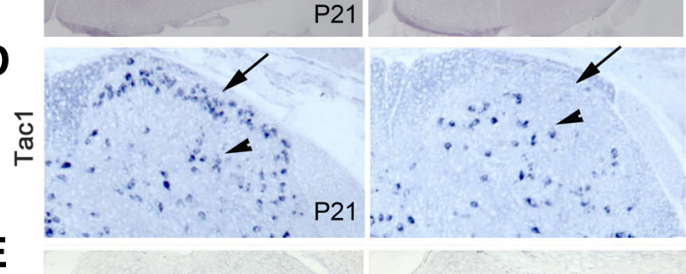

E
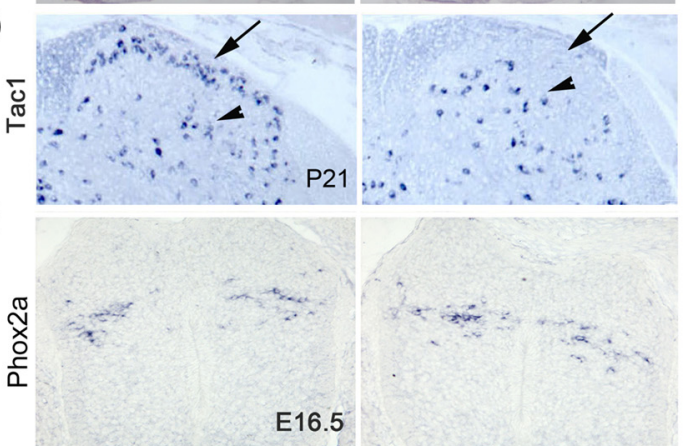
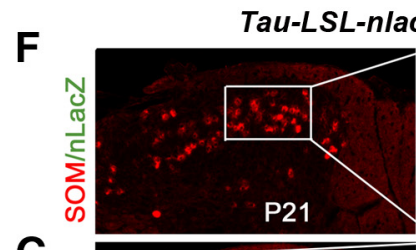

G
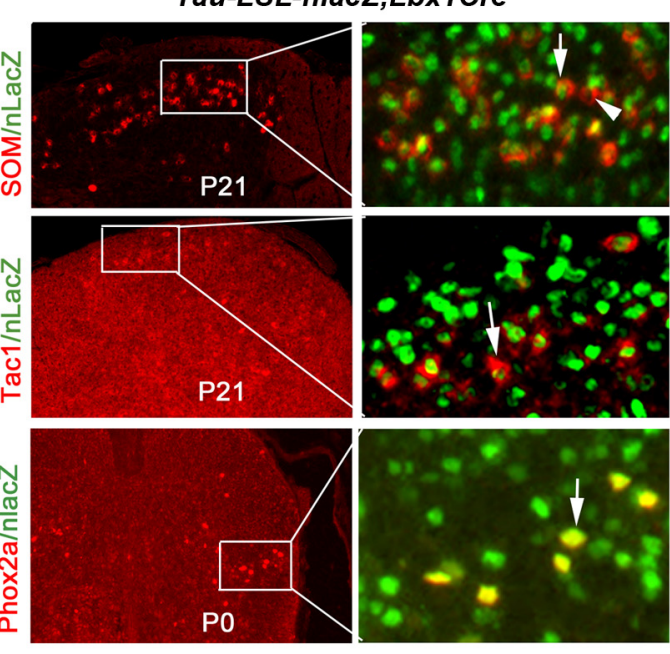

H

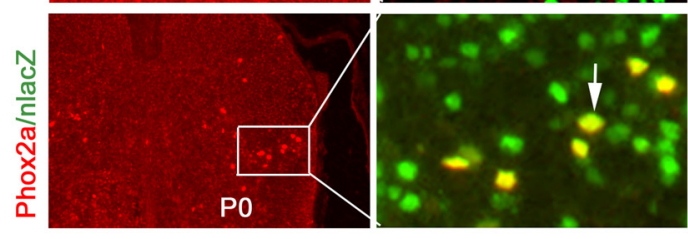

I
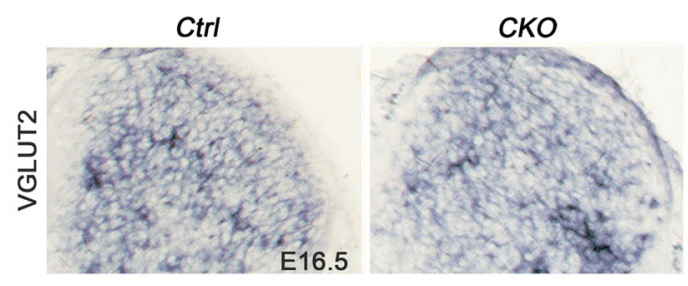

Figure 2. Selective loss of markers in laminae I/II of (KO mice. A, Double immunostaining of TlX3 protein in spinal neurons (green) with VGLUT1 protein in primary afferents (red) on a transverse lumbar spinal section from a P21 wild-type mouse. B, Double staining of the VGLUT1 protein in primary afferent terminals (green) and cytoplasmic SOM mRNA in spinal neurons (pseudo-red, by in situ hybridization) on transverse P21 lumbar spinal cord sections of control (Ctrl) and (KO mice. There is a selective loss of SOM mRNA in lamina I/II dorsal to VGLUT1 ${ }^{+}$terminals (arrow). C, SOM in situ hybridization on transverse P21 spinal sections at the cervical level. Arrow indicates SOM expression in the superficial laminae. D, Tac1 in situ hybridization on transverse P21 lumbar spinal cord sections. Arrows and arrowheads indicate Tac1 expression in superficial and deep laminae, respectively. $\boldsymbol{E}$, Phox2a in situ hybridization on E16.5 lumbar spinal cord sections. $\boldsymbol{F}-\boldsymbol{H}$, Double staining of the nLacZ protein (green) and SOM mRNA ( $\boldsymbol{F}$, red), Tac1 mRNA (G, red), or Phox2a protein (H, red) on P21 or P0 lumbar spinal cord sections from Tau-LSL-nlacZ; Lbx1-Cre fate mapping mice. Arrows and arrowheads indicate double or singular staining, respectively. I, VGLUT2 in situ hybridization on E16.5 lumbar spinal sections with indicated genotypes.

Phox2a (Qian et al., 2002). We again found that these Phox2a ${ }^{+}$ neurons showed normal ventral migration in CKO mice at E16.5 (Fig. 2E) and at P0 (data not shown). Development of Lbx1negative class A spinal neurons is naturally unaffected. For example, dI1 neurons, marked by the expression of BarhL1 (Bermingham et al., 2001; Ding et al., 2012), and dI3 neurons, marked by the expression of Islet 1 (Gross et al., 2002; Müller et al., 2002; Qian et al., 2002), all showed normal ventral migration at E16.5 and P0 in CKO mice compared with controls (data not shown).

The incomplete loss of $\mathrm{SOM}^{+}$and $\mathrm{Tacl}^{+}$neurons, and the normal development of Phox $2 \mathrm{a}^{+}$neurons, does raise a question as to whether or not these neurons originate fully from Lbx ${ }^{+}$class B neurons. To address this, we crossed $L b \times 1$ Cre mice (Sieber et al., 2007) with the Tau-loxp-STOP-lox$m$ GFP-IRES-NLS-LacZ reporter mice (Hippenmeyer et al., 2005) to generate mice referred to here as Tau-LSL-nlacZ; Lbx1-Cre. In these mice, the Lbx1 lineage neurons are marked by the expression of the nuclear lacZ protein, regardless of persistent or transient Lbxl expression. Double staining showed that most, but not all, $\mathrm{SOM}^{+}$neurons coexpressed nLacZ (Fig. $2 F$, arrow vs arrowhead), suggesting that $\mathrm{SOM}^{+}$ neurons originate mainly from $\mathrm{Lbx} 1^{+}$class $\mathrm{B}$ neurons, but also to a lesser degree from $\mathrm{Lbx}^{-}$class A neurons. In addition, most, if not all, Tac1 ${ }^{+}$neurons, as well as all Phox $2 \mathrm{a}^{+}$ neurons coexpressed nlacZ (Fig. 2G,H), suggesting that these neurons are also derived from Lbx1 lineage class B neurons. This finding suggests that the normal development of these Tlx3-transient deep dorsal horn neurons in CKO mice is the result of the preservation of transient Tlx 3 expression in class $B$ neurons, rather than a separate developmental origin from Lbx $1^{-}$class A neurons.

Tlx3 is known to determine glutamatergic over GABAergic neurotransmitter phenotypes, and VGLUT2 expression in the lumbar superficial dorsal horn is eliminated in Tlx3 null mice (Cheng et al., 2004). Interestingly, with the preservation of early Tlx3 expression in CKO mice, VGLUT2 expression was largely unaffected at E16.5 (Fig. 2I). As a comparison, SOM expression in superficial laminae was already eliminated by E16.5 (data not shown). Thus, transient Tlx3 expression is sufficient to establish the glutamatergic transmitter phenotype, which is in contrast with the requirement of Tlx 3 activity beyond E12.5 in establishing other molecular identities, such as the expression of SOM and Tac1 in superficial laminae. 


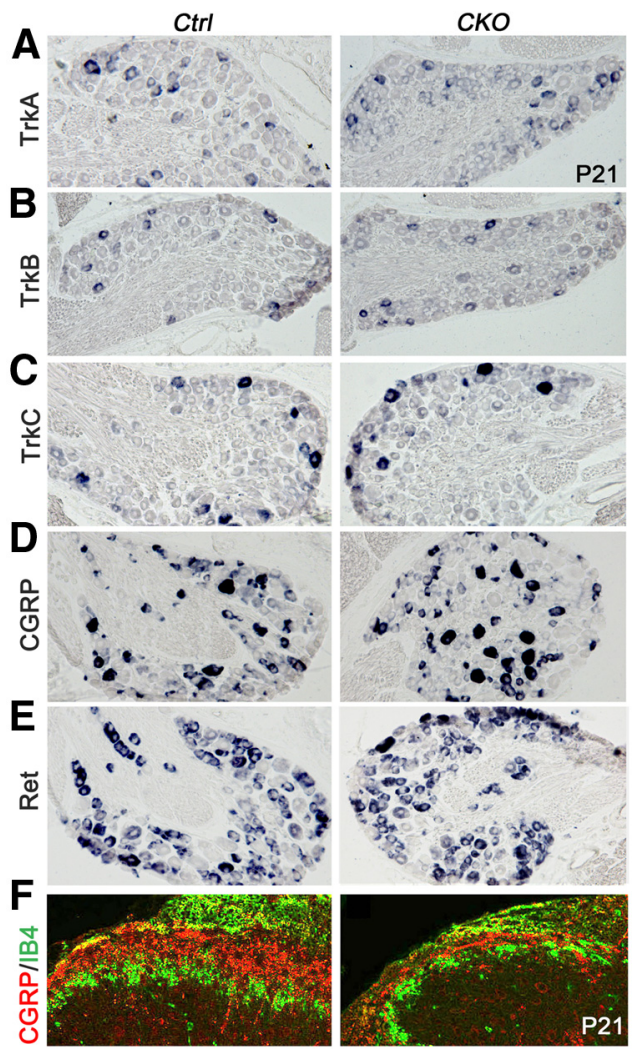

Figure 3. Normal DRG neuron development and reduced central innervation in CKO mice. $\boldsymbol{A}-\boldsymbol{E}$, In situ hybridization with indicated probes on transverse sections through lumbar DRG of P21 control (Ctrl) and CKO mice. F, Double staining on transverse P21 lumbar spinal cord sections with (GRP immunostaining (red) and IB4 binding (green).

\section{Reduced innervation by primary sensory afferents in CKO mice}

Dorsal horn laminae I and II are mainly innervated by sensory neurons detecting pain-, itch-, and temperature-related sensory information (Lallemend and Ernfors, 2012). These sensory neurons, located in the DRG, are divided into two main subtypes, peptidergic and nonpeptidergic neurons. Peptidergic neurons express the calcitonin gene-related peptide (CGRP) and the neurotrophin receptor TrkA, and innervate lamina I and the outer layer of lamina II. Many nonpeptidergic neurons can be labeled by the binding of isolectin B4 (IB4), coexpress the neurotrophin receptor Ret, and innervate the dorsal portion of the inner layer of lamina II. Deep dorsal horn laminae (III-V) are innervated mainly by myelinated mechanoreceptors marked by the expression of various neurotrophin receptors, including TrkC, TrkB, and Ret (Lallemend and Ernfors, 2012), as well as by the expression of VGLUT1 (Li et al., 2003). In CKO mice, DRG neuron development and survival were unaffected, as suggested by the grossly normal expression of TrkA, TrkB, TrkC, CGRP, and Ret (Fig. 3A-E). This is consistent with the lack of Lbx1 expression in DRG (Gross et al., 2002; Müller et al., 2002), and unaffected Tlx3 expression in $T l x 3^{F / F} ; L b x 1^{C r e /+}$ CKO mice (data not shown).

Despite normal differentiation of DRG neurons, we found that there are much fewer $\mathrm{CGRP}^{+}$and $\mathrm{IB}^{+}{ }^{+}$nerve terminals in CKO dorsal spinal cord, although their relative dorsoventral projection pattern remained (Fig. $3 F$ ). In contrast, innervation of VGLUT1 ${ }^{+}$low threshold mechanoreceptors to the deep dorsal horn and to the ventral motor neurons was largely unaffected (data not shown). Thus, developmental impairment of a large subset of Tlx3-dependent excitatory neurons in the superficial dorsal horn results in reduced innervation by $\mathrm{CGRP}^{+}$and $\mathrm{IB}^{+}$ afferents, but the basic organization of these terminals in the dorsal horn is preserved in CKO mice.

\section{Impaired behavioral responses evoked by pain-related stimuli in $C K O$ mice}

CKO mice can only survive for 1-2 months. These mutant mice showed overgrowth of teeth, possibly leading to malocclusion that may affect feeding (Fig. $4 A$ ), but the underlying cause is not known. Nonetheless, CKO mice at 3-4 weeks of age grossly looked healthy, although their body sizes were smaller than wildtype littermates (data not shown). We therefore performed all behavioral analyses at these ages, with $T l x 3^{F / F}$ or $T l x 3^{F /+}$ littermates as controls.

CKO mice showed normal proprioception and sensorimotor coordination, as suggested by proper clustering of the forelimbs and the extension of hindlimbs when suspended by the tail (Fig. $4 B)$. Furthermore, after one round of training, CKO and control littermates remained on an accelerating rotarod for similar amounts of time (Fig. 4C).

We next applied a mechanical stimulus to the plantar surface of the hindpaw using von Frey fibers and determined the threshold leading to hindpaw lifting and flinching. In comparison with controls, CKO mice showed a marked increase in withdrawal thresholds, suggesting a deficit in generating proper reflex behavior in response to noxious mechanical stimuli (Fig. 4D).

To measure behavioral response to noxious heat, we placed mice on a hot plate set to $50^{\circ} \mathrm{C}$ or $54^{\circ} \mathrm{C}$ and found that the latency of hindpaw lifting/flinching increased markedly in CKO mice, suggesting a defect in processing heat-related sensory information (Fig. $4 E, F$ ). Heat pain is mediated by DRG neurons expressing the transient receptor potential channel TRPV1 (Cavanaugh et al., 2009; Mishra and Hoon, 2010), which is also the receptor for the chili pepper ingredient capsaicin (Caterina et al., 1997). Consistently, intraplantar capsaicin injection, which evoked robust licking and flinching in controls, failed to elicit responses in CKO mice (Fig. 4G).

To more directly assess how spinal neurons responded to painful stimuli in CKO mice, we took advantage of the previous finding that noxious painful stimuli, such as $50^{\circ} \mathrm{C}$ heat, activate the ERK protein kinase through phosphorylation (p-ERK) selectively in lamina I/II neurons (Ji et al., 1999). We found that, after $50^{\circ} \mathrm{C}$ heat stimulation of the $\mathrm{CKO}$ hindpaw for a short period $(20$ $\mathrm{s})$, the number of $\mathrm{p}$-ERK ${ }^{+}$neurons in superficial laminae of the lumbar spinal cord was greatly reduced compared with controls, from $190 \pm 44$ per set of sections in control mice to $31 \pm 9$ in CKO mice ( $n=4, p<0.05$ ), an $84 \%$ reduction (Fig. $4 H, I$ ). Together, these data suggest that Tlx3-dependent dI5 and/or dIL neurons are required to process mechanical and heat pain-related sensory information.

\section{Reduced scratching response evoked by pruritic compounds in $\mathrm{CKO}$ mice}

To measure itch-related behavior, we performed nape injections of itch-inducing compounds and monitored scratching response. Compound 48/80 activates a histamine-dependent itch pathway (Sugimoto et al., 1998), and the number of scratch bouts evoked by this compound was reduced, but not completely eliminated, in CKO mice compared with controls (Fig. 5A). Both the malaria drug chloroquine and the Par2 agonist peptide SLIGRL$\mathrm{NH} 2$ evoke histamine-independent itch by activating the G-protein coupled receptors Mrgpra3 and Mrgprc11, respectively (Liu et al., 2009, 2011; Wilson et al., 2011). Nape injection 
A

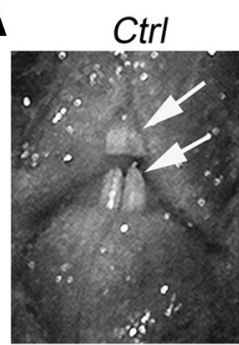

D
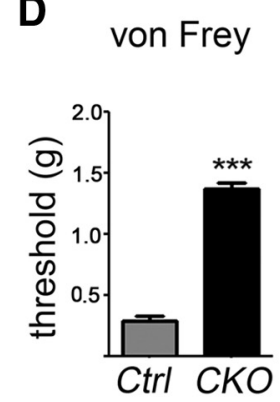

H

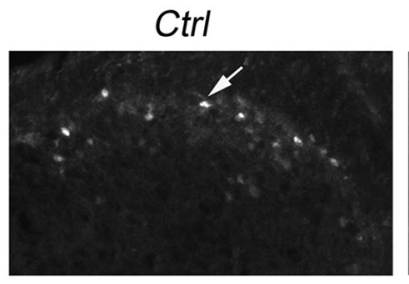

CKO

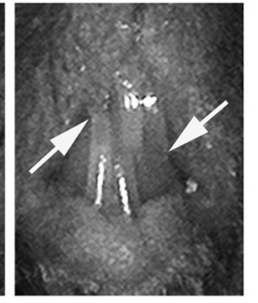

B

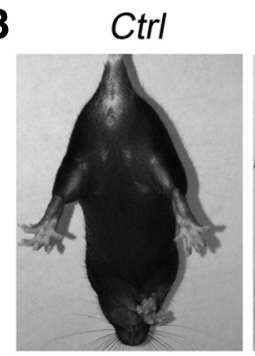

E $\quad 50^{\circ} \mathrm{C}$

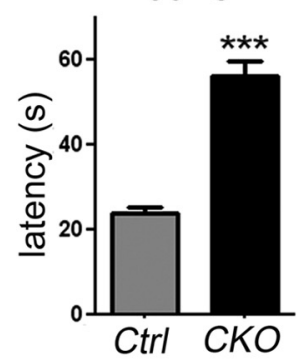

F

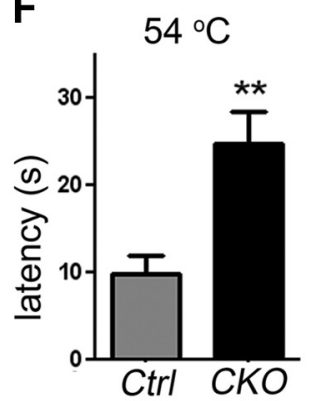

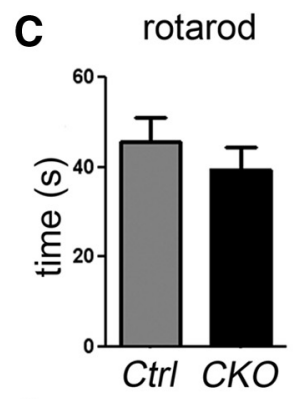

G

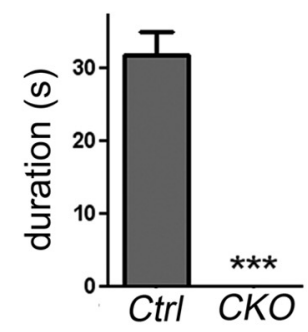

I

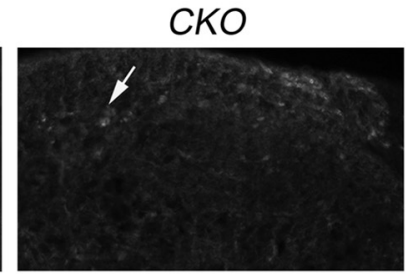

Figure 4. Long teeth, normal sensorimotor coordination and impaired nocifensive behaviors in CKO mice. $A$, Malocclusion in a P28 CKO mouse (arrows) compared with a control (Ctrl). B, P28 CKO mice exhibiting normal sensorimotor coordination. C, Rotarod assay. No significant difference was found between (trl and CKO mice on time (seconds) staying on accelerating rotarod. Ctrl, $n=10$, $45.6 \pm 5.5 \mathrm{~s} ; C K 0, n=10,39.4 \pm 5.2 \mathrm{~s} . p=0.44$. D, von Frey test. CKO mice showed a higher withdrawal threshold than Ctrl mice. $C$ trl, $n=7,0.29 \pm 0.04 \mathrm{~g} ; C K 0, n=7,1.36 \pm 0.05 \mathrm{~g} .{ }^{* * *} p<$ 0.001. E, F, Hot plate assay. CKO mice showed longer latency (seconds) in response to both $50^{\circ} \mathrm{C}$ and $54^{\circ} \mathrm{C}$ stimuli compared with $\mathrm{Ctrl}$ mice. $\boldsymbol{E}$, For $50^{\circ} \mathrm{C}: \mathrm{Ctrl}, n=8,23.4 \pm 1.2 \mathrm{~s} ; \mathrm{CKO}, n=8,56.5 \pm$ $1.0 \mathrm{~s} .{ }^{* * *} p<0.001$. F, For $54^{\circ} \mathrm{C}: \mathrm{Ctrl}, n=6,7.6 \pm 1.0 \mathrm{~s} ; \mathrm{CKO}, n=6,26.8 \pm 1.3 \mathrm{~s} .{ }^{* *} p<0.01$. G, Capsaicin hindpaw injection assay: measuring the duration (seconds) of licking and flinching. Abolished response in $C K O$ mice. Ctrl, $n=9,31.8 \pm 3.2 \mathrm{~s} ; \mathrm{CKO}, n=9,0.0 \pm 0.0 \mathrm{~s}$. H, p-ERK immunostaining on P28 lumbar spinal transverse sections after heat stimulation. Arrows indicate superficial laminae. I, Quantitative analysis of $\mathrm{p}$-ERK ${ }^{+}$neurons per set of sections through L3-L6. CtrI, $n=4,190 \pm 44 ; C K O, n=4,31 \pm 9$. ${ }^{*} p<0.05$. Error bars indicate SEM.

of these compounds evoked robust scratching responses in control littermates, but little in CKO mice. Thus, Tlx3-dependent dI5 and/or $\mathrm{dIL}_{\mathrm{b}}$ class $\mathrm{B}$ excitatory neurons are required to process itch-related information (Fig. 5A).

Dorsal horn neurons expressing GRPR, the receptor for the GRP, have been implicated in itch sensing (Sun et al., 2009). We found that expression of both GRPR and GRP was eliminated in CKO mice (Fig. 5B).

Double staining on spinal sections of Tau-LSL-nlacZ;Lbx1Cre fate-mapping mice showed that neurons with detectable GRPR or GRP mRNA coexpressed nLacZ (Fig. 5C,D), suggesting that $\mathrm{GRPR}^{+}$and $\mathrm{GRP}^{+}$neurons represent subsets of Lbx ${ }^{+}{ }^{+}$class $B$ neurons. To further investigate the ontogeny of GRPR ${ }^{+}$neurons, we crossed Tlx3-Cre mice with the Tau-LSL-nLacZ reporter mice, with Tlx3 lineage spinal neurons permanently marked by the expression of nlacZ (Hippenmeyer et al., 2005; Xu et al., 2008). Double staining showed that $\mathrm{GRPR}^{+}$neurons are confined to Tlx3 lineage excitatory neurons (Fig. $5 E$ ). Consistently, $\mathrm{GRPR}^{+}$neurons did not express Pax2 (Fig. 5F), which is a marker for inhibitory neurons (Cheng et al., 2004). Collectively, these studies suggest that Tlx3 may autonomously control the development of itch-related $\mathrm{GRPR}^{+}$neurons.
Impairment of touch-evoked escape responses in CKO mice In response to the dynamic mechanical stimulus of stroking the hindpaw with a cotton swab, control mice responded by lifting the hindpaw and walking away. Interestingly, this touch-evoked "escape" response was virtually abolished in CKO mice (Fig. 6A). To assess the potential cause for this behavioral deficit, we next examined neurons expressing the $\gamma$ isoform of PKC $\gamma$ in the inner lamina II, which respond to dynamic mechanical stimuli (Miraucourt et al., 2007; Neumann et al., 2008) and belong to excitatory neurons (Polgár et al., 1999). We found that PKC $\gamma$ expression in the inner lamina II was eliminated in CKO mice (Fig. 6B). As a positive control, $\mathrm{PKC} \gamma^{+}$fibers in the dorsal funiculus were still detected in both control and mutant mice (Fig. 6B).

Consistently, double staining on spinal sections of Tau-LSLnlacZ;Lbx1-Cre fate-mapping mice showed that all $\mathrm{PKC} \gamma^{+}$neurons coexpressed nlacZ (Fig. 6C), suggesting that they represent Lbx1 lineage class B neurons. Furthermore, many, although not all, $\mathrm{PKC} \gamma^{+}$neurons showed persistent Tlx3 expression (Fig. 6D). The location of $\mathrm{PKC} \gamma^{+}$neurons delineates the ventral border of Tlx3-persistent neurons (Fig. 6D). We hypothesized that the impaired development of $\mathrm{PKC} \gamma^{+}$mechanoresponsive cells might underlie the loss of the escape response evoked by dynamic me- 
A

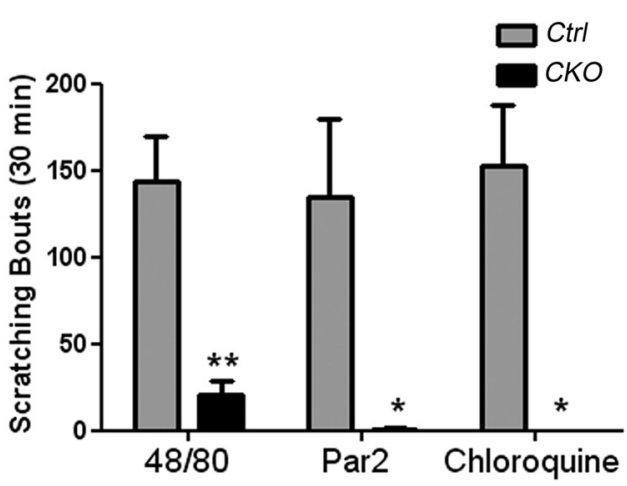

B

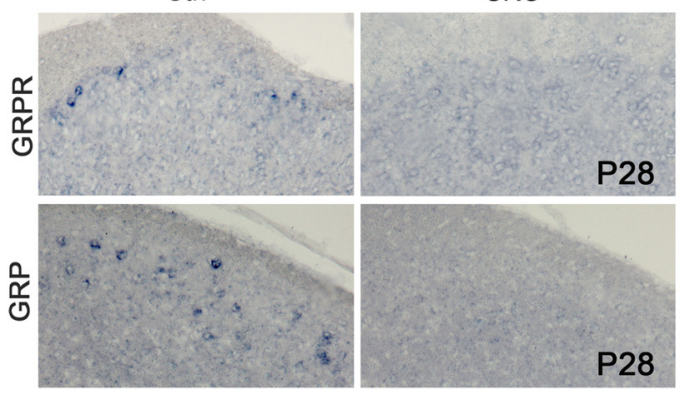

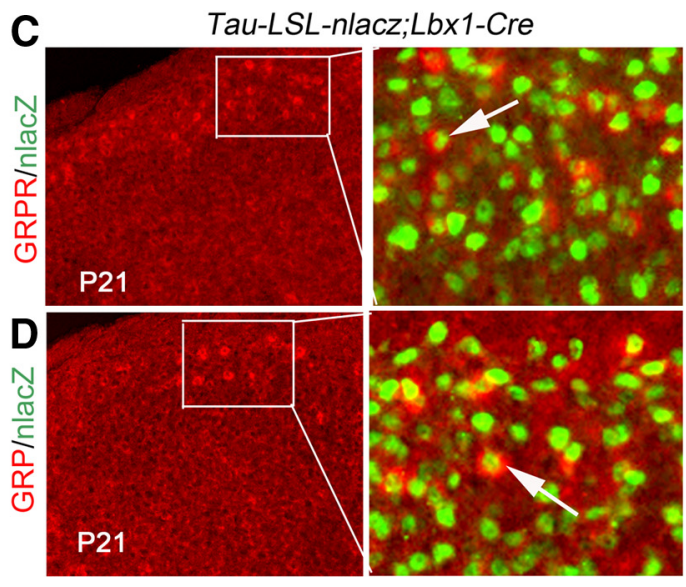

Tau-LSL-nlacZ;TIx3-Cre
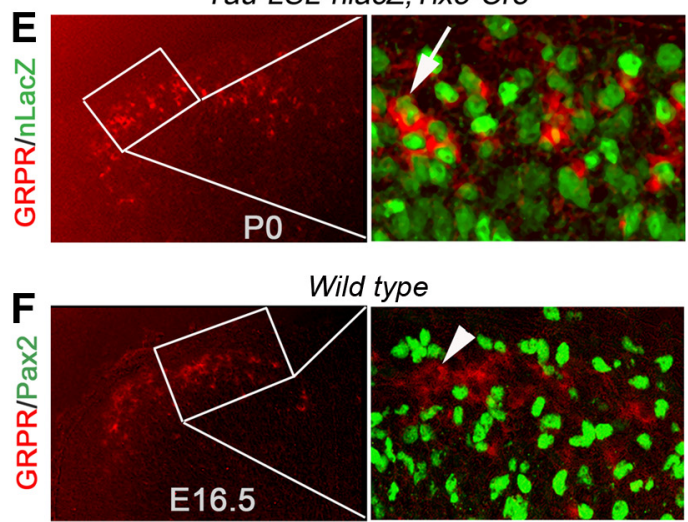

Figure 5. Impaired scratching response evoked by pruritic compounds in CKO mice. $A$, Scratching response was examined in animals at 3 to 4 weeks old. Nape injections of compound $48 / 80$ (10 $\mu$ g) evoked reduced scratching bouts in CKO mice compared with controls ( $($ trl) $)$. (trl, $n=6,149 \pm 74 ; C K O, n=6,21 \pm 19$. ${ }^{* *} p<0.01$. Injection of the PAR2 agonistSLIGRL-NH2 (100 $\mu \mathrm{g}$ ) evoked virtually no scratching in CKO mice. Ctrl, $n=6,134 \pm 111 ; C K O, n=6,1 \pm 2$. ${ }^{*} p<0.05$. Injection of chloroquine injection $(200 \mu \mathrm{g})$ also did not induce scratching in mutants. Ctrl, $n=4,152 \pm 70 ; C K 0, n=4,0 \pm 0$. ${ }^{*} p<0.05$. Error bars indicate SEM. $\boldsymbol{B}$, In situ hybridization on P28 lumbar spinal cord sections with indicated probes. $C, D, G R P R{ }^{+}$and GRP ${ }^{+}$neurons are derived from Lbx1 lineage neurons. Double staining of the nLaCZ protein (green) and indicated mRNA (pseudo-red) on P21 lumbar spinal cord sections from Tau-LSL-nlacZ;Lbx1-Cre fate mapping mice. Arrows indicate colocalization. E, GRPR ${ }^{+}$neurons are derived from TIX3 lineage neurons. Double staining of the nLacZ protein (green) and GRPR mRNA (pseudo-red) on PO lumbar spinal cord sections of Tau-LSL-nlacZ; TIX3-Cre fate mapping mice. Arrows indicate colocalization. $\boldsymbol{F}$, Double staining of the nuclear Pax2 protein (green) and GRPR mRNA (pseudo-red) on an E16.5 wild-type spinal section, showing no colocalization (arrowhead).

chanical stimuli in CKO mice, although future studies are needed to test this hypothesis.

\section{CKO mice are able to sense innocuous cooling and/or warm,} but not noxious cold

We next examined how mutants responded to cold stimuli. We first placed controls and mutants onto the cold plate set to $0^{\circ} \mathrm{C}$ for $2 \mathrm{~min}$. We found that most control mice exhibited paw lifting and licking, but these nocifensive responses evoked by noxious cold were virtually abolished in CKO mice (Fig. 7A). We next performed the acetone evaporation assay, which cools skin temperature down to $14-18^{\circ} \mathrm{C}$, around the transition zone of noxious versus innocuous cold temperatures (Colburn et al., 2007). We found that both CKO mice and control littermates showed similar responses to the evaporative cooling as measured by the duration of paw shaking, lifting, and licking (Fig. $7 B$ ), suggesting that $T l \times 3$ CKO mice appear to retain the ability to sense innocuous or mild noxious cold.

To further explore whether $C K O$ mice were able to sense innocuous cold, we performed the temperature chamber selection assay (Bautista et al., 2007; Colburn et al., 2007; Dhaka et al., 2007; Knowlton et al., 2010). We found that mutant and control mice were indistinguishable in choosing the $30^{\circ} \mathrm{C}$ over the room temperature $\left(\sim 20^{\circ} \mathrm{C}\right)$ chamber, or the $20^{\circ} \mathrm{C}$ chamber over the $15^{\circ} \mathrm{C}$ or $5^{\circ} \mathrm{C}$ chamber (Fig. $7 \mathrm{C}$ ). The normal selection of $30^{\circ} \mathrm{C}$ over $20^{\circ} \mathrm{C}$ chambers suggests that $C K O$ mice are able to sense innocuous cooling and/or warm. In the $20^{\circ} \mathrm{C}$ versus $5^{\circ} \mathrm{C}$ assay, some investigators used the avoidance of the $5^{\circ} \mathrm{C}$ chamber as a way of measuring noxious cold sensation (Bautista et al., 2007; Colburn et al., 2007; Dhaka et al., 2007; Knowlton et al., 2010). However, both mutant and control mice spent $\sim 94 \%$ of time in the $20^{\circ} \mathrm{C}$ chamber (Fig. $7 \mathrm{C}$ ): the moment they reached the $5^{\circ} \mathrm{C}$ chamber, they immediately withdrew to the warmer side (data not shown). Such momentary exposure to the cold chamber unlikely drops the skin temperature to the noxious cold range. Thus, the normal selection of $20^{\circ} \mathrm{C}$ over $5^{\circ} \mathrm{C}$ by $C K O$ mice most likely reflects a normal sense of innocuous cooling, rather than cold pain, particularly considering that these mice fail to generate pain-suggestive responses at $0^{\circ} \mathrm{C}$ (Fig. $7 A$ ). Collectively, these findings suggest that $C K O$ mice fail to respond to extreme cold but retain the ability to sense innocuous cooling and/or warm.

\section{Discussion}

\section{Temporal control of dorsal horn excitatory} neuron phenotypes

$T l \times 3$ and its related gene $T l x 1$ act as selector genes that coordinate the development of a diverse array of dorsal horn excitatory neurons by specifying glutamatergic and peptidergic transmitter 
A
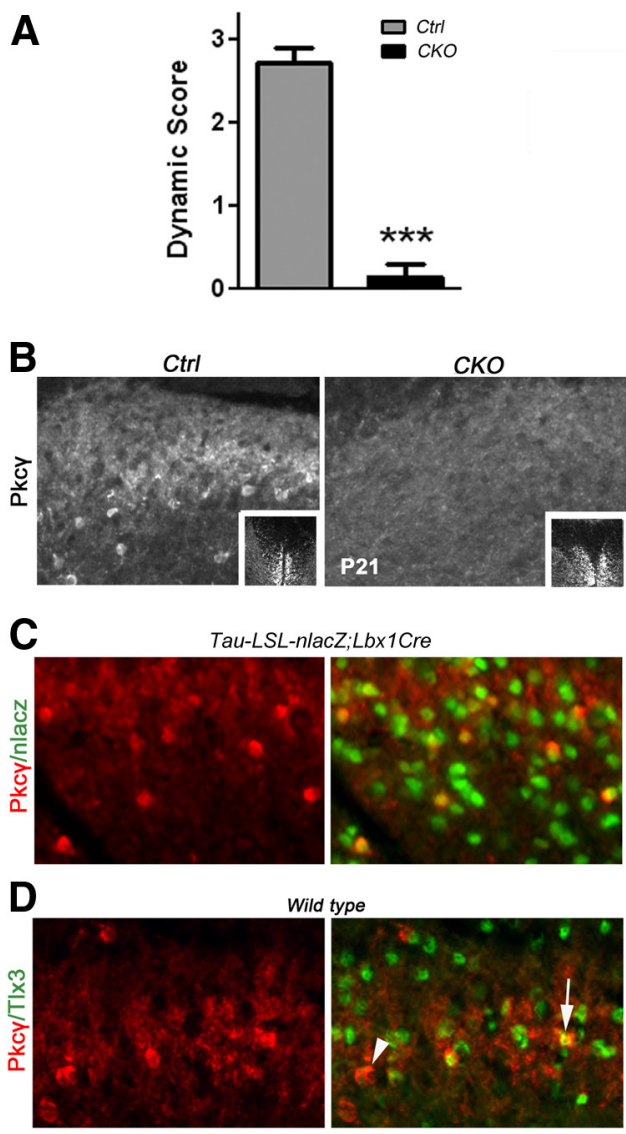

Figure 6. Impairment of touch-evoked escape responses and Pkc $\gamma^{+}$neurons in $C K O$ mice. $A$, The cotton wipe assay. The dynamic score, used to measure touch-evoked escapes, was reduced in CKO mice compared with control littermates ( $(\mathrm{trl})$. $C \mathrm{Crl}, n=7,2.71 \pm 0.18$; $C K O$, $n=7,0.14 \pm 0.14$. ${ }^{* * *} p<0.05$. B Immunostaining of Pkc on P21 lumbar spinal cord sections at indicated genotypes. Insets, Pkc staining within the dorsal funiculus. $\mathbf{C}, \operatorname{Pkc} \gamma^{+}$neurons are derived from $L b x 1$ lineage neurons. Double staining of the $L$ LacZ protein (green) and Pkc $\gamma($ red) on P21 lumbar spinal cord sections from Tau-LSL-nlacZ;Lbx1-Cre fate mapping mice. D, Double staining of Pkc protein (red) with TIx3 protein (green) on a P21 wild-type transverse lumbar spinal cord section. Arrow indicates colocalization; arrowhead indicates Pkc neurons lacking Tlx3.

phenotypes as well as controlling transmitter receptor expression (Qian et al., 2002; Cheng et al., 2004; Xu et al., 2008; Guo et al., 2012). Tlx1 is expressed in a subset of excitatory neurons of the cervical/thoracic spinal cord, and its expression is switched off once postmitotic neurons migrate out of the ventricular zone (Qian et al., 2002). In our CKO mice, Tlx3 expression was detected normally at E12.5 but largely eliminated by E16.5. That is, expression of both Tlx 1 and Tlx3 becomes transient throughout the spinal cord in $C K O$ mice.

A comparison of phenotypes of $T l \times 3$ null versus $C K O$ mice provides insight into the temporal control of dorsal horn excitatory neuron phenotypes. We found that transient Tlx3 expression retained in CKO mice is sufficient to activate VGLUT2 in the dorsal horn, in contrast to complete loss of VGLUT2 expression at the lumbar superficial dorsal horn in Tlx3 null mice (Cheng et al., 2004). The early determination of the glutamatergic transmitter phenotype is consistent with that VGLUT2 expression is initiated shortly after birth of neurons and that transient Tlx1 expression in the cervical/thoracic dorsal horn is able to compensate Tlx3 loss in establishing VGLUT2 expression (Cheng et al., 2004). In contrast, expression of SOM, Tac1, GRP, GRPR, and $\mathrm{PKC} \gamma$ in laminae I/II is eliminated in CKO mice, suggesting a
A

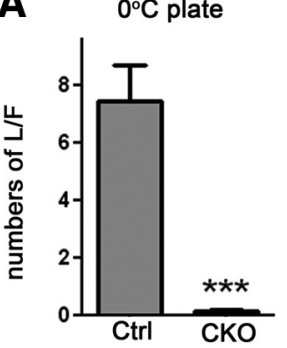

B acetone
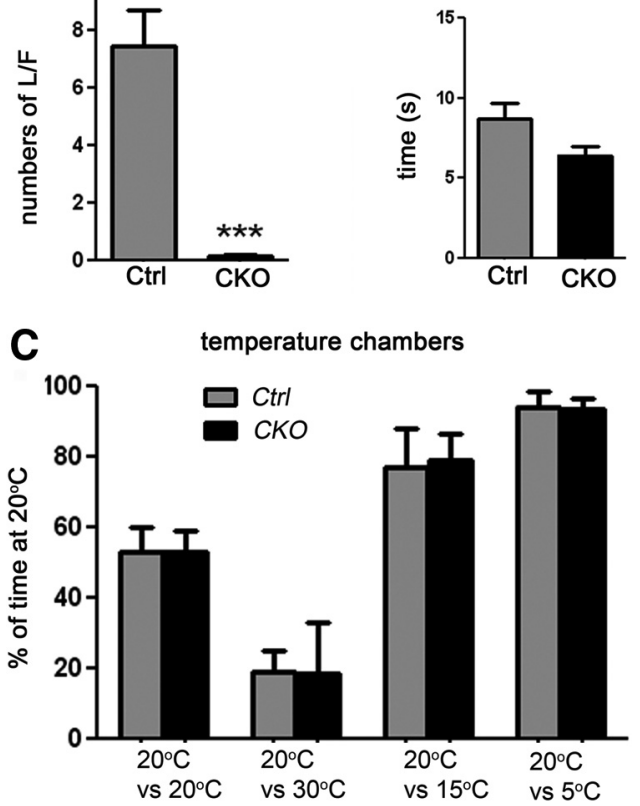

Figure 7. Cold behavior analyses. $\boldsymbol{A}$, The $0^{\circ} \mathrm{C}$ cold plate assay. The numbers of licking/flinching ("L/F") were counted. The CKO mice failed to respond to noxious cold ( $\mathrm{Ctrl}, n=20,7.45 \pm$ $0.13 ;(K 0, n=5,1.27 \pm 0.08) .{ }^{* * *} p<0.001$. $\boldsymbol{B}$, The acetone evaporation assay. No difference between control and CKO mice (Ctrl, $n=7,8.73 \pm 0.97 ;(K 0, n=5,6.40 \pm 0.57) . p>0.05$. C, The temperature chamber selection assay. The percentages of time staying at the $20^{\circ} \mathrm{C} \mathrm{cham-}$ ber were determined. No differences between control and CKO mice were observed at four different sets of temperatures. For $20^{\circ} \mathrm{C}$ versus $20^{\circ} \mathrm{C}$ selection chamber: control, $n=6,52.8 \pm$ $6.8 ; \mathrm{CKO}, n=6,52.9 \pm 56.0$. $p=0.8$. For $20^{\circ} \mathrm{C}$ versus $30^{\circ} \mathrm{C}$ : control, $n=6,18.6 \pm 6.4 ; \mathrm{CKO}$, $n=6,18.4 \pm 14.5 . p=0.9$. For $20^{\circ} \mathrm{C}$ versus $15^{\circ} \mathrm{C}$ : control, $n=6,76.9 \pm 11.0 ;$ CKO, $n=6$, $78.8 \pm 7.4 . p=0.9$. For $20^{\circ} \mathrm{C}$ versus $5^{\circ} \mathrm{C}$ : control, $n=6,94.0 \pm 4.5 ;$ CKO $n=6,93.5 \pm 2.9$. $p=0.4$.

requirement of Tlx3 activity beyond E12.5 in establishing this set of molecular identities. Transient Tlx1 expression is unable to compensate this late Tlx3 activity, resulting in a loss of SOM and other markers at both lumbar and cervical levels (Fig. 2). Thus, early and late Tlx protein activities establish distinct molecular identities in dorsal horn excitatory neurons.

\section{Ontogeny of spinal neurons processing distinct sensory modalities}

The dorsal horn excitatory neurons are divided into Lbx ${ }^{-}$class A neurons (dI1-dI3) and $\mathrm{Lbxl}^{+}$class B neurons ( $\mathrm{dI} 5$ and $\mathrm{dIL}_{\mathrm{B}}$ ) (Figs. $1 A$ and 8 ). Our studies and others show that this molecular and developmental subdivision is correlated with distinct sensory modalities processed by these spinal neurons. Two class A neurons ( $\mathrm{dI} 1$ and $\mathrm{dI} 3$ ) are located in the deep dorsal horn laminae and involved with sensory-motor coordination, with dI1 neurons necessary for proprioception (Bermingham et al., 2001) and dI3 neurons involved with hand grasp performance (Bui et al., 2013). The studies described here show that Tlx3-dependent class $\mathrm{B}$ excitatory neurons ( $\mathrm{dI} 5$ and/or $\mathrm{dIL}_{\mathrm{B}}$ ) are required to process pain-related and itch-related sensory information and to generate the escape response in response to dynamic mechanical stimuli (Fig. 8).

Class B neurons can be further divided into two categories (I and II), based on how their development is affected in $T l \times 3^{F / F}$; Lbx $1^{\mathrm{Cre} /+}$ CKO mice. The first category (Fig. 8, "I") includes those whose development is unaffected in CKO mice, such as the 


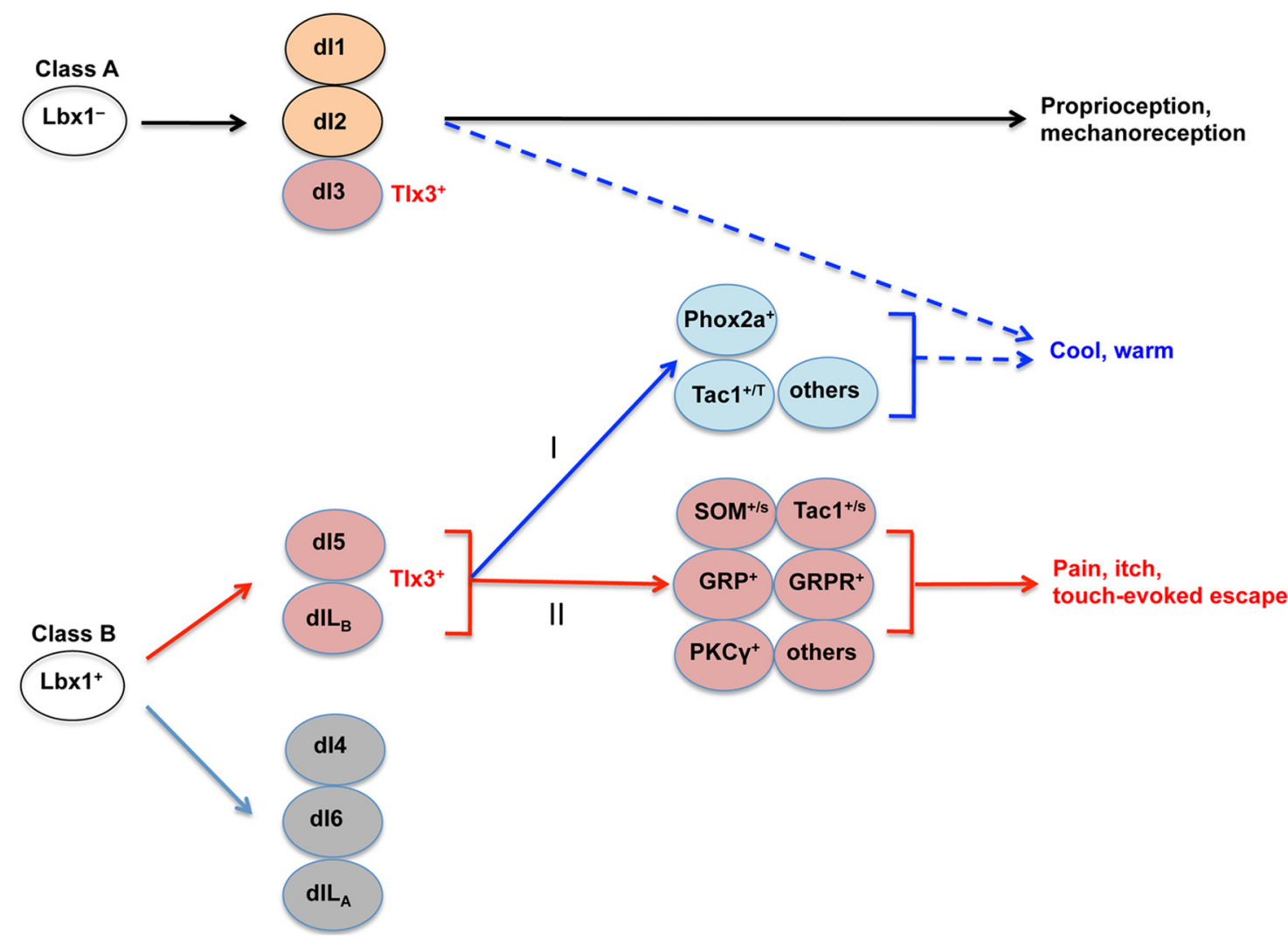

Figure 8. Ontogeny of spinal neurons processing distinct sensory modalities. I and II are referred to as two categories of Lbx $1^{+}$class B excitatory neurons. Type I includes neurons whose development is unaffected in CKO mice, whereas Type II category is composed of a cohort of neurons whose development is impaired in CKO mice. Type II neurons are located in laminae I/I and are required to generate nocifensive motor behaviors evoked by pain-related or itch-related stimuli, as well as to generate escape response evoked by dynamic mechanical stimuli. Lbx $1^{-}$class $\mathrm{A}$ neurons mediate proprioceptive and mechanoreceptive sensory information. However, it is not clear whether the sense of innocuous cold or warm, which is preserved in $C K O$ mice, is mediated by $\mathrm{Lbx} 1^{-}$class A neurons or by the Type I category of $\mathrm{Lbx} 1^{+}$class B excitatory neurons (dashed arrows). SOM ${ }^{+/ 5}$ and Tac $1^{+/ 5}, \mathrm{SOM}{ }^{+}$and Tac $1^{+}$neurons at laminae I/II, or the superficial ("s") laminae.

Phox $2 \mathrm{a}^{+}$subset of dI5 neurons and a portion of $\mathrm{Tac}^{+}{ }^{+}$neurons located in deep laminae. Genetic fate mapping shows that both Phox $2 \mathrm{a}^{+}$and $\mathrm{Tacl}^{+}$neurons do represent $\mathrm{Lbx1}{ }^{+}$class B neurons (Fig. 2). We reported previously that Tlx3 expression is switched off soon after the genesis of these neurons at E11.5 or E12.5 (Qian et al., 2002; Xu et al., 2008). Accordingly, the preservation of transient Tlx3 expression in $C K O$ mice explains a normal development of these neurons. Because the CKO mice retain the ability to sense innocuous cold and/or warm, we speculate that this type of somatic sensory information might be processed by Type I category of class B excitatory neurons or by Lbx1-negative class A neurons, whose development is also unaffected in CKO mice (Fig. 8, dashed arrows).

The second category (Fig. 8, "II") of class B excitatory neurons are those whose development is compromised in $C K O$ mice, such as $\mathrm{SOM}^{+}, \mathrm{Tacl}^{+}, \mathrm{GRP}^{+}, \mathrm{GRPR}^{+}$, and $\mathrm{PKC} \gamma^{+}$neurons located in laminae I and II. Genetic fate mapping shows that all these neurons represent Lbx1 lineage neurons, with the exception of a small subset of $\mathrm{SOM}^{+}$neurons. Our behavioral analyses show that this category of Tlx3-dependent neurons are specialized to process pain-related and itch-related information, as well as to generate the touch-evoked escape response. An involvement of Tlx3-dependent spinal neurons in sensing pain is consistent with that mice lacking DRG11/Prrxl1, a Tlx3-dependent gene (Qian et al., 2002), exhibited marked deficits in generating nocifensive behavior in response to painful stimuli (Chen et al., 2001), although the interpretation is complicated by a latter report show- ing a concurrent requirement of DRG11/Prrxl1 for DRG neuron development (Rebelo et al., 2006). Among type II class B neurons, $\mathrm{GRPR}^{+}$and $\mathrm{GRP}^{+}$neurons have already been implicated in processing itch (Sun et al., 2009; Mishra and Hoon, 2013). The identities of spinal neurons processing pain-related information are still poorly understood, but $\mathrm{SOM}^{+}$and/or $\mathrm{Tacl}^{+}$neurons, representing two large subsets of excitatory neurons located in laminae I/II, could be attractive candidates. $\mathrm{PKC} \gamma^{+}$neurons respond to dynamic mechanical stimuli (Miraucourt et al., 2007; Neumann et al., 2008); their developmental impairment might contribute to the loss of the touch-evoked escape response in $C K O$ mice.

Among spinal neurons responding to low threshold mechanical stimuli, $\mathrm{PKC} \gamma^{+}$neurons are unique in terms of their location in the inner layer of lamina II (Neumann et al., 2008), rather than in the more conventional laminae III-V (Kandel et al., 2000; Lallemend and Ernfors, 2012). Here, we showed that these neurons are derived from Lbx $1^{+}$class B neurons, rather than from Lbx ${ }^{-}$ class A neurons that mainly settle in laminae III-V (Helms and Johnson, 2003). Moreover, upon central disinhibition after peripheral nerve injury, $\mathrm{PKC} \gamma^{+}$neurons are part of the circuit that mediates pain evoked by low threshold mechanical stimuli (Takazawa and MacDermott, 2010). It should also be noted that touch-evoked escape is a conserved behavior seen in worms, insects, fishes, and mammals and likely evolves for animals to escape from predators in the natural environment. Thus, the shared developmental ontogeny of the type II class B excitatory 
neurons appears to be correlated with the shared roles in sensing environmental danger and generating proper behavior to avoid noxious stimuli or to escape from predators (Fig. 8).

In 1905, Henry Head performed nerve injury studies on his own arm (Head, 1905); and based on differential speeds of sensory fiber regeneration and sequential recovery of distinct sensory modalities, he discovered two constituents of cutaneous sensibility: (1) the "protopathic" system, responding to painful stimuli and to the extremes of heat and cold, the kind of stimuli that evoke strong reflex but are poorly localized; and (2) the "epicritic" system, responding to innocuous stimulations permitting fine discriminations of temperature and touch. In our Tlx3 CKO mice, processing of "protopathic"like sensory modalities (e.g., the senses of pain and itch) appears to be selectively compromised, whereas processing of "epicritic" sensory information (e.g., proprioception and the sense of innocuous cold or warm) is preserved (summarized in Fig. 8). Thus, Henry Head's distinction between epicritic and protopathic peripheral sensory modalities might be mapped at the level of the spinal cord as well. Our studies thereby provide novel insight into the ontogeny of spinal neurons processing distinct somatic sensory modalities.

\section{References}

Bautista DM, Siemens J, Glazer JM, Tsuruda PR, Basbaum AI, Stucky CL, Jordt SE, Julius D (2007) The menthol receptor TRPM8 is the principal detector of environmental cold. Nature 448:204-208. CrossRef Medline

Bermingham NA, Hassan BA, Wang VY, Fernandez M, Banfi S, Bellen HJ, Fritzsch B, Zoghbi HY (2001) Proprioceptor pathway development is dependent on Math1. Neuron 30:411-422. CrossRef Medline

Bui TV, Akay T, Loubani O, Hnasko TS, Jessell TM, Brownstone RM (2013) Circuits for grasping: spinal dI3 interneurons mediate cutaneous control of motor behavior. Neuron 78:191-204. CrossRef Medline

Caterina MJ, Schumacher MA, Tominaga M, Rosen TA, Levine JD, Julius D (1997) The capsaicin receptor: a heat-activated ion channel in the pain pathway. Nature 389:816-824. CrossRef Medline

Cavanaugh DJ, Lee H, Lo L, Shields SD, Zylka MJ, Basbaum AI, Anderson DJ (2009) Distinct subsets of unmyelinated primary sensory fibers mediate behavioral responses to noxious thermal and mechanical stimuli. Proc Natl Acad Sci U S A 106:9075-9080. CrossRef Medline

Chaplan SR, Bach FW, Pogrel JW, Chung JM, Yaksh TL (1994) Quantitative assessment of tactile allodynia in the rat paw. J Neurosci Methods 53:55-63. CrossRef Medline

Chen ZF, Rebelo S, White F, Malmberg AB, Baba H, Lima D, Woolf CJ, Basbaum AI, Anderson DJ (2001) The paired homeodomain protein DRG11 is required for the projection of cutaneous sensory afferent fibers to the dorsal spinal cord. Neuron 31:59-73. CrossRef Medline

Cheng L, Arata A, Mizuguchi R, Qian Y, Karunaratne A, Gray PA, Arata S, Shirasawa S, Bouchard M, Luo P, Chen CL, Busslinger M, Goulding M, Onimaru H, Ma Q (2004) Tlx3 and Tlx1 are post-mitotic selector genes determining glutamatergic over GABAergic cell fates. Nat Neurosci 7:510-517. CrossRef Medline

Cheng L, Samad OA, Xu Y, Mizuguchi R, Luo P, Shirasawa S, Goulding M, Ma Q (2005) Lbx1 and Tlx3 are opposing switches in determining GABAergic versus glutamatergic transmitter phenotypes. Nat Neurosci 8:1510-1515. CrossRef Medline

Christensen BN, Perl ER (1970) Spinal neurons specifically excited by noxious or thermal stimuli: marginal zone of the dorsal horn. J Neurophysiol 33:293-307. Medline

Colburn RW, Lubin ML, Stone DJ Jr, Wang Y, Lawrence D, D’Andrea MR, Brandt MR, Liu Y, Flores CM, Qin N (2007) Attenuated cold sensitivity in TRPM8 null mice. Neuron 54:379-386. CrossRef Medline

Craig AD (2003) Pain mechanisms: labeled lines versus convergence in central processing. Annu Rev Neurosci 26:1-30. CrossRef Medline

Dhaka A, Murray AN, Mathur J, Earley TJ, Petrus MJ, Patapoutian A (2007) TRPM8 is required for cold sensation in mice. Neuron 54:371-378. CrossRef Medline

Ding Q, Joshi PS, Xie ZH, Xiang M, Gan L (2012) BARHL2 transcription factor regulates the ipsilateral/contralateral subtype divergence in postmi- totic dI1 neurons of the developing spinal cord. Proc Natl Acad Sci U S A 109:1566-1571. CrossRef Medline

Glasgow SM, Henke RM, Macdonald RJ, Wright CV, Johnson JE (2005) Ptfla determines GABAergic over glutamatergic neuronal cell fate in the spinal cord dorsal horn. Development 132:5461-5469. CrossRef Medline

Gross MK, Dottori M, Goulding M (2002) Lbxl specifies somatosensory association interneurons in the dorsal spinal cord. Neuron 34:535-549. CrossRef Medline

Guo Z, Zhao C, Huang M, Huang T, Fan M, Xie Z, Chen Y, Zhao X, Xia G, Geng J, Cheng L (2012) Tlx1/3 and Ptfla control the expression of distinct sets of transmitter and peptide receptor genes in the developing dorsal spinal cord. J Neurosci 32:8509-8520. CrossRef Medline

Han ZS, Zhang ET, Craig AD (1998) ) Nociceptive and thermoreceptive lamina I neurons are anatomically distinct. Nat Neurosci 1:218-225. CrossRef Medline

Head H (1905) The afferent nervous system from a new aspect. Brain 28:100-115.

Helms AW, Johnson JE (2003) Specification of dorsal spinal cord interneurons. Curr Opin Neurobiol 13:42-49. CrossRef Medline

Hippenmeyer S, Vrieseling E, Sigrist M, Portmann T, Laengle C, Ladle DR, Arber S (2005) A developmental switch in the response of DRG neurons to ETS transcription factor signaling. PLoS Biol 3:e159. CrossRef Medline

Hökfelt T (1991) Neuropeptides in perspective: the last ten years. Neuron 7:867-879. CrossRef Medline

Ji RR, Baba H, Brenner GJ, Woolf CJ (1999) Nociceptive-specific activation of ERK in spinal neurons contributes to pain hypersensitivity. Nat Neurosci 2:1114-1119. CrossRef Medline

Kandel ER, Schwartz JH, Jessell TM (2000) Principles of neural science, Ed 4. New York: McGraw-Hill.

Knowlton WM, Bifolck-Fisher A, Bautista DM, McKemy DD (2010) TRPM8, but not TRPA1, is required for neural and behavioral responses to acute noxious cold temperatures and cold-mimetics in vivo. Pain 150: 340-350. CrossRef Medline

Knowlton WM, Daniels RL, Palkar R, McCoy DD, McKemy DD (2011) Pharmacological blockade of TRPM8 ion channels alters cold and cold pain responses in mice. PLoS One 6:e25894. CrossRef Medline

Lallemend F, Ernfors P (2012) Molecular interactions underlying the specification of sensory neurons. Trends Neurosci 35:373-381. CrossRef Medline

Li JL, Fujiyama F, Kaneko T, Mizuno N (2003) Expression of vesicular glutamate transporters, VGluT1 and VGluT2, in axon terminals of nociceptive primary afferent fibers in the superficial layers of the medullary and spinal dorsal horns of the rat. J Comp Neurol 457:236-249. CrossRef Medline

Liu Q, Tang Z, Surdenikova L, Kim S, Patel KN, Kim A, Ru F, Guan Y, Weng HJ, Geng Y, Undem BJ, Kollarik M, Chen ZF, Anderson DJ, Dong X (2009) Sensory neuron-specific GPCR Mrgprs are itch receptors mediating chloroquine-induced pruritus. Cell 139:1353-1365. CrossRef Medline

Liu Q, Weng HJ, Patel KN, Tang Z, Bai H, Steinhoff M, Dong X (2011) The distinct roles of two GPCRs, MrgprC11 and PAR2, in itch and hyperalgesia. Sci Signal 4:ra45. CrossRef Medline

Liu Y, Abdel Samad O, Zhang L, Duan B, Tong Q, Lopes C, Ji RR, Lowell BB, Ma Q (2010) VGLUT2-dependent glutamate release from peripheral nociceptors is required to sense pain and suppress itch. Neuron 68:543556. CrossRef Medline

Lopes C, Liu Z, Xu Y, Ma Q (2012) Tlx3 and Runxl act in combination to coordinate the development of a cohort of nociceptors, thermoceptors, and pruriceptors. J Neurosci 32:9706-9715. CrossRef Medline

Miraucourt LS, Dallel R, Voisin DL (2007) Glycine inhibitory dysfunction turns touch into pain through PKCgamma interneurons. PLoS One 2:e1116. CrossRef Medline

Mishra SK, Hoon MA (2010) Ablation of TrpV1 neurons reveals their selective role in thermal pain sensation. Mol Cell Neurosci 43:157-163. CrossRef Medline

Mishra SK, Hoon MA (2013) The cells and circuitry for itch responses in mice. Science 340:968-971. CrossRef Medline

Mishra SK, Holzman S, Hoon MA (2012) A nociceptive signaling role for neuromedin B. J Neurosci 32:8686-8695. CrossRef Medline

Müller T, Brohmann H, Pierani A, Heppenstall PA, Lewin GR, Jessell TM, Birchmeier C (2002) The homeodomain factor Lbxl distinguishes two 
major programs of neuronal differentiation in the dorsal spinal cord. Neuron 34:551-562. CrossRef Medline

Müller T, Anlag K, Wildner H, Britsch S, Treier M, Birchmeier C (2005) The bHLH factor Olig 3 coordinates the specification of dorsal neurons in the spinal cord. Genes Dev 19:733-743. CrossRef Medline

Neumann S, Braz JM, Skinner K, Llewellyn-Smith IJ, Basbaum AI (2008) Innocuous, not noxious, input activates PKCgamma interneurons of the spinal dorsal horn via myelinated afferent fibers. J Neurosci 28:79367944. CrossRef Medline

Polgár E, Fowler JH, McGill MM, Todd AJ (1999) The types of neuron which contain protein kinase $\mathrm{C}$ gamma in rat spinal cord. Brain Res 833:71-80. CrossRef Medline

Qian Y, Fritzsch B, Shirasawa S, Chen CL, Choi Y, Ma Q (2001) Formation of brainstem (nor)adrenergic centers and first-order relay visceral sensory neurons is dependent on homeodomain protein Rnx/Tlx3. Genes Dev 15:2533-2545. CrossRef Medline

Qian Y, Shirasawa S, Chen CL, Cheng L, Ma Q (2002) Proper development of relay somatic sensory neurons and D2/D4 interneurons requires homeobox genes Rnx/Tlx3 and Tlx1. Genes Dev 16:1220-1233. CrossRef Medline

Rebelo S, Chen ZF, Anderson DJ, Lima D (2006) Involvement of DRG11 in the development of the primary afferent nociceptive system. Mol Cell Neurosci 33:236-246. CrossRef Medline

Rebelo S, Reguenga C, Lopes C, Lima D (2010) Prrxl1 is required for the generation of a subset of nociceptive glutamatergic superficial spinal dorsal horn neurons. Dev Dyn 239:1684-1694. CrossRef Medline
Shirasawa S, Arata A, Onimaru H, Roth KA, Brown GA, Horning S, Arata S, Okumura K, Sasazuki T, Korsmeyer SJ (2000) Rnx deficiency results in congenital central hypoventilation. Nat Genet 24:287-290. CrossRef Medline

Sieber MA, Storm R, Martinez-de-la-Torre M, Müller T, Wende H, Reuter K, Vasyutina E, Birchmeier C (2007) Lbxl acts as a selector gene in the fate determination of somatosensory and viscerosensory relay neurons in the hindbrain. J Neurosci 27:4902-4909. CrossRef Medline

Sugimoto Y, Umakoshi K, Nojiri N, Kamei C (1998) Effects of histamine H1 receptor antagonists on compound 48/80-induced scratching behavior in mice. Eur J Pharmacol 351:1-5. CrossRef Medline

Sun YG, Zhao ZQ, Meng XL, Yin J, Liu XY, Chen ZF (2009) Cellular basis of itch sensation. Science 325:1531-1534. CrossRef Medline

Takazawa T, MacDermott AB (2010) Synaptic pathways and inhibitory gates in the spinal cord dorsal horn. Ann N Y Acad Sci 1198:153-158. CrossRef Medline

Todd AJ (2010) Neuronal circuitry for pain processing in the dorsal horn. Nat Rev Neurosci 11:823-836. CrossRef Medline

Wilson SR, Gerhold KA, Bifolck-Fisher A, Liu Q, Patel KN, Dong X, Bautista DM (2011) TRPAl is required for histamine-independent, Mas-related G protein-coupled receptor-mediated itch. Nat Neurosci 14:595-602. CrossRef Medline

Xu Y, Lopes C, Qian Y, Liu Y, Cheng L, Goulding M, Turner EE, Lima D, Ma Q (2008) Tlx1 and Tlx3 coordinate specification of dorsal horn painmodulatory peptidergic neurons. J Neurosci 28:4037-4046. CrossRef Medline 